\title{
Expression of fragile $X$ mental retardation protein and Fmr1 mRNA during folliculogenesis in the rat
}

\author{
Ianina Ferder ${ }^{1}$, Fernanda Parborell ${ }^{1}$, Victoria Sundblad ${ }^{1}$, Violeta Chiauzzi ${ }^{1}$, Karina Gómez ${ }^{2}$, \\ Eduardo $\mathrm{H}$ Charreau $^{1}$, Marta Tesone ${ }^{1,3}$ and Liliana Dain ${ }^{1,4}$ \\ ${ }^{1}$ Instituto de Biología y Medicina Experimental (IBYME)- CONICET, Vuelta de Obligado 2490, C1428ADN Ciudad de \\ Buenos Aires, Argentina, ${ }^{2}$ Instituto de Investigaciones en Ingeniería Genética y Biología Molecular (INGEBI)- \\ CONICET, Vuelta de Obligado 2490, C1428ADN Ciudad de Buenos Aires, Argentina, ${ }^{3}$ Departamento de Química \\ Biológica, Facultad de Ciencias Exactas y Naturales, Universidad de Buenos Aires, Intendente Güiraldes 2160, Ciudad \\ Universitaria, C1428EGA Ciudad de Buenos Aires, Argentina and ${ }^{4}$ Centro Nacional de Genética Médica, ANLIS, \\ Dr Carlos G. Malbrán, Las Heras 2670, 3er piso, C1425ASQ Ciudad de Buenos Aires, Argentina
}

Correspondence should be addressed to L Dain at Instituto de Biología y Medicina Experimental (IByME)- CONICET; Email: Idain@fbmc.fcen.uba.ar

\begin{abstract}
Fragile X mental retardation protein (FMRP) belongs to a small family of RNA-binding proteins. Its absence or inactivity is responsible for fragile $X$ syndrome, the most common cause of inherited mental retardation. Despite its ubiquitous expression, FMRP function and expression remain almost understudied in non-neuronal tissues, though previous studies on germline development during oogenesis may suggest a special function of this protein also in ovarian tissue. In addition, the well-documented association of FMR1 premutation state with fragile X-related premature ovarian insufficiency adds interest to the role of FMRP in ovarian physiology. The aim of the present work was to investigate the expression of Fmr1 mRNA and its protein, FMRP, at different stages of rat follicular development. By immunohistochemical studies we demonstrated FMRP expression in granulosa, theca and germ cells in all stages of follicular development. In addition, changes in Fmr1 expression, both at the protein and mRNA levels, were observed. FMRP levels increased upon follicular development while preantral and early antral follicles presented similar levels of Fmr1 transcripts with decreased expression in preovulatory follicles. These observations suggest that Fmr1 expression in the ovary is regulated at different and perhaps independent levels. In addition, our results show expression of at least four different isoforms of FMRP during all stages of follicular growth with expression patterns that differ from those observed in brain and testis. Our study shows a regulated expression of Fmr1, both at mRNA and protein levels, during rat follicular development.

Reproduction (2013) 145 335-343
\end{abstract}

\section{Introduction}

Fragile X mental retardation protein (FMRP) belongs to a small family of RNA-binding proteins. It contains several motifs involved in binding to RNA: two heterogeneous nuclear ribonucleoprotein (hnRNP)-K-homology $(\mathrm{KH})$ domains and an arginine-glycine-glycine (RGG box). The protein is encoded by the FMR1 gene, which is composed of 17 exons, spans about $40 \mathrm{~kb}$ and encodes an mRNA of $3.9 \mathrm{~kb}$ that can be alternatively spliced into a number of different isoforms (Eichler et al. 1993, Verkerk et al. 1993). In addition, FMRP has been shown to undergo two post-translational modifications: phosphorylation and arginine methylation (Siomi et al. 2002, Stetler et al. 2006). It has been suggested that phosphorylation might modulate FMRP properties such as association with actively translating polyribosomes and with Dicer (Ceman et al. 2003, Cheever
\& Ceman 2009) while methylation affects both its protein-protein and protein-RNA interactions (Denman 2002, Dolzhanskaya et al. 2006, Stetler et al. 2006, Blackwell et al. 2010, Blackwell \& Ceman 2012). The presence of a nuclear localization signal and a nuclear export signal suggests shuttling between the nucleus and the cytoplasm (Eberhart et al. 1996). Nevertheless, FMRP is mostly in the cytoplasm (Devys et al. 1993), where it is found associated with polyribosomes as part of large messenger-ribounucleoprotein (mRNP) particles. The FMRP-mRNP complex contains several other proteins including fragile $X$ mental retardation syndrome-related protein 1; (FXR1P) and FXR2 (FXR2P) (Tamanini et al. 1996, Ceman et al. 1999, 2000). Notably, the absence or inactivity of FMRP is responsible for fragile $X$ syndrome (FXS), the most common cause of inherited mental retardation (for review, see O'Donnell \& Warren (2002)). Strong evidence supports a role of FMRP in the 
regulation of specific target mRNA translation; moreover, dysregulation of protein synthesis at the neuronal synapse has been proposed as one of the mechanisms underlying FXS (Brown et al. 2001, Laggerbauer et al. 2001, Mazroui et al. 2002). Results obtained from several studies suggest that the microRNA pathway may be one of the mechanisms by which FMRP could modulate mRNA translation. Studies in Drosophila have demonstrated an interaction of Drosophila fmr1 (dFmr1) with artgonaute 2 (AGO2) and Dicer, both components of the iRNA machinery, which suggests that $d F m r 1$ is part of the RNA-induced silencing complex (RISC) in Drosophila (Caudy et al. 2002, Ishizuka et al. 2002). Similarly, mammalian FMRP has been shown to interact in vivo with microRNA (miRNA) and with the components of the miRNA pathway (Jin et al. 2004). Notably, though FMRP expression is ubiquitous, it is most abundantly expressed in neurons and testis (Devys et al. 1993, Tamanini et al. 1997, Bakker et al. 2000), both tissues affected in fragile $X$ patients. In mice, an enhanced expression of Fmr1 during germ cell proliferation was described, suggesting a special function for Fmr1 in germ cells of both sexes (Bachner et al. 1993). Interestingly, a more recent study using Drosophila dFmr1 mutants demonstrated that $d F m r 1$ is required for germline stem cell maintenance and repression of differentiation in the ovary, probably via the miRNA pathway (Yang et al. 2007). Another Drosophila FXS model showed that FMRP controls germline proliferation during oogenesis by regulating the expression of casitas B-lineage lymphoma proto-oncogene $(c b /)$ in the developing ovary (Epstein et al. 2009).

Notably, the UTR of the FMR1 gene presents a CGG repeat that is unstable and therefore variable in the population. Based on the size of the expansion, individuals are classified as having normal (5-54 trinucleotide repeats), premutated (55-200 repeats), or fully mutated (>200 repeats) alleles (Fu et al. 1991, Oberle et al. 1991, Rousseau et al. 1995). Full mutated alleles usually result in hypermethylation of the CpG site in the promoter region of the FMR1 gene (Bell et al. 1991), which leads to gene silencing; the subsequent absence of the protein is therefore responsible for FXS. Conversely, carriers of the premutation have increased levels of FMR1 mRNA (twofold to eightfold in lymphocytes) due to increased transcription rate of the gene (Tassone et al. 2000, 2007). Premutation state is associated with two clinical disorders: fragile $\mathrm{X}$-associated tremor/ataxia syndrome (FXTAS), a lateonset neurodegenerative disorder, and fragile X-related premature ovarian insufficiency (FXPOI). The increased levels of CGG-containing FMR1 mRNA along with the presence of ubiquitin-positive intranuclear inclusions observed in both neurons and astrocytes of FXTAS patients and in animal models led to the suggestion that a toxic RNA gain of function mechanism may underlie FXTAS development. Indeed, inclusions were also found in tissues other than the CNS in subjects with
FXTAS (e.g. testicles and peripheral nerve ganglia) (for review, see Garcia- Arocena \& Hagerman (2010)). FXPOI is defined as premutation carriers having menopause before the age of 40 years, ovarian dysfunction, and decreased fertility (Allingham-Hawkins et al. 1999). Based on several studies, $\sim 20 \%$ of premutation carriers have FXPOI compared to only $1 \%$ in the general population. Conversely, among women with idiopathic sporadic premature ovarian failure, $\sim 2-14 \%$ are estimated to carry a FMR1 premutation (Sherman 2000).

Despite its ubiquitous expression FMRP function and expression remain almost understudied in non-neuronal tissues. Though within the periphery FMRP is most abundantly expressed in the testis, previous studies on germline development during oogenesis may suggest a special function of this protein in ovarian tissue as well. Indeed, the well-documented association of premutation state with FXPOI adds interest to the question of the role of FMRP in ovarian physiology. Considering that to date the function of this protein in the ovary has been barely explored, a detailed description of the expression of FMR1 during ovarian development seems necessary. Thus, in the present work we aimed to investigate the expression of Fmr1 mRNA and its protein, FMRP, at different stages of rat follicular development.

\section{Results \\ Follicular granulosa and theca cells express FMRP at all stages of folliculogenesis}

Results of immunohistochemical staining for FMRP in ovarian sections from untreated, diethylstilbestrol (DES)or PMSG-treated prepubertal rats is shown in Fig. 1. Follicles at different developmental stages can be distinguished by their morphological features, such as size and number of granulosa cell (GC) layers. Preantral follicles (PAF) present an oocyte surrounded by two to four layers of GC and are $120-200 \mu \mathrm{m}$ in diameter, whereas a small antral cavity and a thin theca layer can be distinguished in early antral follicles (EAF), which are about 300-400 $\mu \mathrm{m}$ in diameter. The oocyte becomes acentrically displaced by the developing antrum in preovulatory follicles (PF), which present a well-defined and thick granulosa layer and are more than $450 \mu \mathrm{m}$ in diameter (Hirshfield \& Midgley 1978).

In sections from untreated rats, FMRP staining was seen in GC and theca cells (TC) as well as in the stroma of PAF (Fig. 1A), but no differences in intensity could be distinguished between different cell types. No staining was observed in the ovarian cortex while the oocyte cytoplasm in primordial follicles showed intense labeling (Fig. 1D).

In ovaries from DES- and PMSG-treated rats, intense FMRP immunostaining was observed in GC and TC as well as in the few stromal cells that can be found at these late stages of development (Fig. 1B and C). 
In ovaries at all three stages of folliculogenesis, no positive staining was detected in the stromal cells surrounding the follicles; it is worth noting that these stromal cells might belong to the vascular network
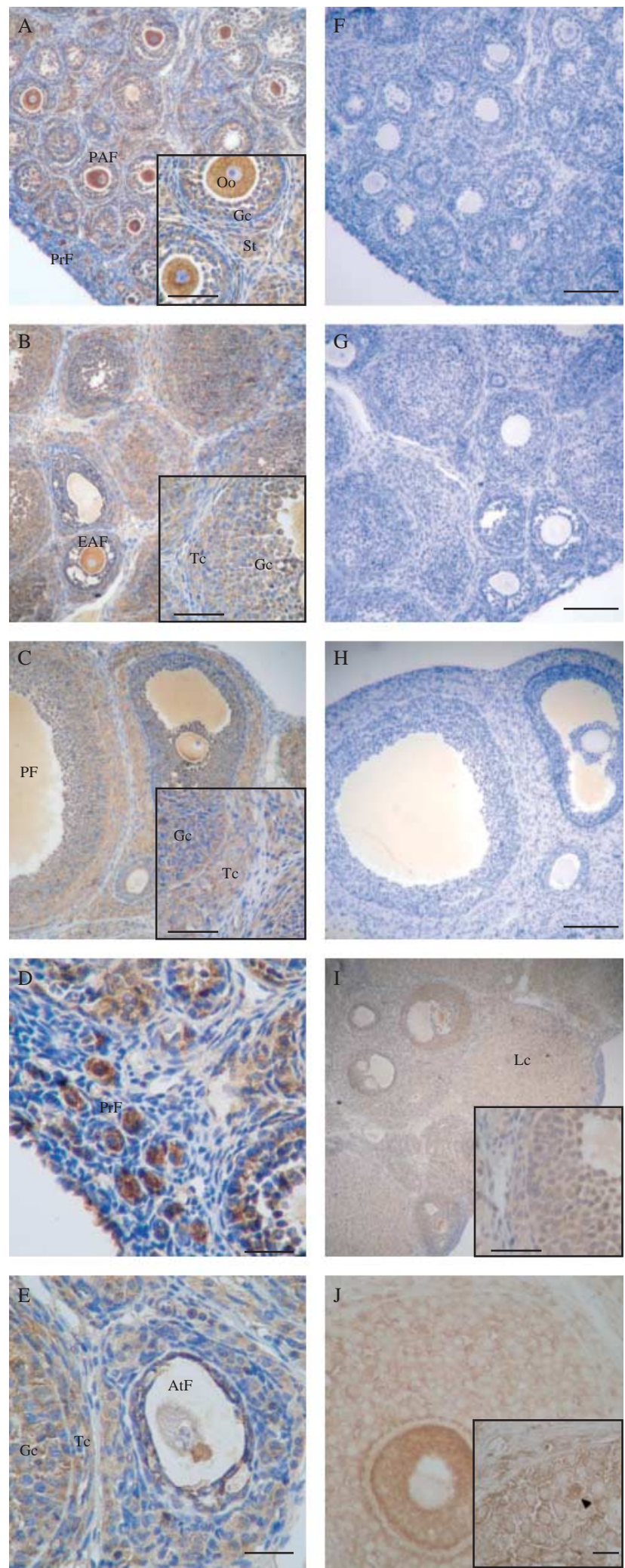

(Fig. 1A, B and C). FMRP staining in atretic follicles was weaker than in healthy ones (Fig. 1E). The oocyte showed positive immunostaining in all follicular stages studied. The FMRP expression pattern was similar among follicles of the same type from prepubertal, DES- and PMSG-treated rats. Furthermore, when analyzing untreated 60-day-old postpubertal cycling rats we observed a similar expression pattern of FMRP at each follicular stage between hormonally untreated and treated immature female rats. Expression of FMRP was also detected in luteal cells of these adult rats (Fig. 1I). In addition, FMRP labeling in the nucleus was detected only in a small fraction of the cells (Fig. 1), and data not shown).

\section{FMRP expression increases as the follicle grows}

FMRP expression in isolated follicles and in whole ovaries was analyzed by western blot (WB) in all three experimental groups (untreated, DES- or PMSG-treated prepubertal rats). When isolated follicles were analyzed FMRP expression was low in PAF and increased progressively in EAF and PF (Fig. 2A). Though the differences did not reach statistical significance, a clear tendency to a higher expression in PF was observed. Four isoforms of the protein could be detected; all of them proportionally increased their expression as folliculogenesis progressed. Considering that most expected isoforms have similar molecular weights and might therefore be hard to discriminate in a polyacrylamide gel, the presence of additional variants cannot be ruled out.

The differences in FMRP expression observed during folliculogenesis persisted when analysis was performed relative to expression levels of S6, another ribosomal protein (Fig. 2A), ruling out a generalized increment of ribosomal protein synthesis during follicular development. In addition when whole ovary proteins were analyzed the same FMRP expression pattern was observed (data not shown).

Given the well-documented high expression of FMRP in testis and brain (Devys et al. 1993, Tamanini et al. 1997, Bakker et al. 2000), and the lack of FMRP expression in skeletal muscle (Devys et al. 1993, Khandjian et al. 1998, Bakker et al. 2000), these tissues

Figure 1 Immunohistochemical staining for FMRP during follicular development in the rat ovary. (A) Untreated prepubertal rats.

(B) DES-treated prepubertal rats. (C) PMSG-treated prepubertal rats.

(D) Primordial follicles from untreated prepubertal rats. (E) Atretic follicle from DES-treated rats. $(\mathrm{F}, \mathrm{G}$ and $\mathrm{H})$ Negative controls without 1C3 antibody (F, prepubertal rats; G, DES-treated rats; H, PMSG-treated rats). (I) Untreated postpubertal cycling rats. (J) Nuclei from DES-treated rats without hematoxylin counterstain (arrowhead, stained nucleus). $\mathrm{PAF}$, preantral follicle; PrF, primordial follicle; Oo, oocyte; Gc, granulosa cells; Tc, theca cells; St, stroma; AtF, atretic follicle; Lc, luteal cells; EAF early antral follicle; PF, preovulatory follicle. Scale bars represent (A, B, C, D, E and I) $50 \mu \mathrm{m}$; (F, G and H) $100 \mu \mathrm{m}$; and (J) $20 \mu \mathrm{m}$. 
were used as positive and negative controls respectively (Fig. 2B and C). As shown in Fig. 2B, a high expression of the protein was observed in the testis. Four isoforms were also expressed in this tissue but their relative expression differed from that observed in the ovary. While no significant differences were observed in the expression levels of the diverse isoforms in the ovary, the highmolecular-weight isoforms were more abundant in both testis and brain (Fig. 2B).

\section{Fmr1 mRNA expression}

Following the analysis of protein expression, we aimed to determine whether protein synthesis correlated with gene expression rate at mRNA level. Fmr1-specific primers amplify a region of mRNA in which no splicing events occur and thus the results obtained correspond to all possible transcribed isoforms. As shown, the Fmr1 mRNA expression pattern was opposite to the one obtained for protein expression: the lowest values of mRNA were observed in PMSG-treated rats, both in isolated PF (Fig. 3A) and in the whole ovary (Fig. 3B), and these differences were statistically significant $(P<0.05)$. When other tissues were analyzed as controls, a clear tendency toward a higher expression was observed in the testis, while similar levels were detected in muscle, brain, and ovarian follicles (Fig. 3C).

\section{Discussion}

The FMR1 gene is transcribed and translated in many tissues including the ovary. Nevertheless, and despite the well-documented association of FMR 1 premutation CGG trinucleotide repeats (range 55-200) and FXPOI the physiological expression and function of the gene in follicular development remain barely explored. So far, the function of FMRP in the ovary has been studied in Drosophila models, where it may be involved in germ cell and oocyte specification (Costa et al. 2005, Megosh et al. 2006) as well as in the maintenance of germline stem cells, probably regulating the translation of specific mRNAs via the miRNA pathway (Yang et al. 2007). A role in the control of germline proliferation was also demonstrated (Epstein et al. 2009), thus suggesting an early stage-specific function of Fmr1 in germ cells.

In this study we demonstrated changes in Fmr1 expression, both at the protein and mRNA levels, and described FMRP cellular localization at different stages of follicular development in the rat ovary. We used untreated, DES- and PMSG-treated prepubertal rats in order to include the most representative stages of ovarian follicular development. This rat model is suitable for our purpose as in the immature ovary (mainly composed of PAF/EAF), DES and PMSG hormonal treatment triggers
A
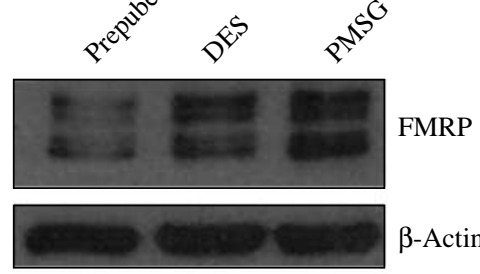

S6
B

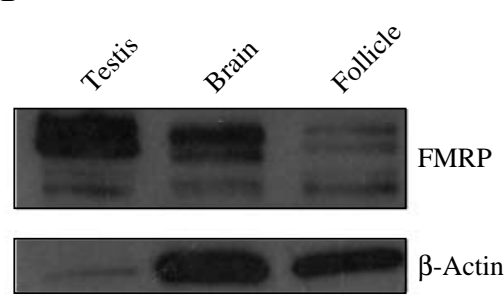

C

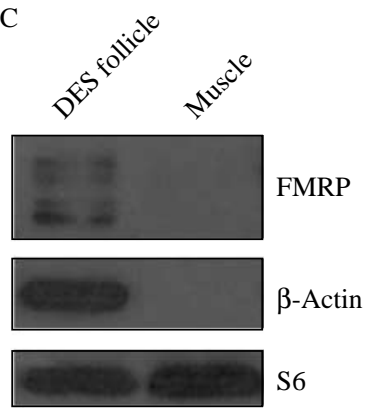

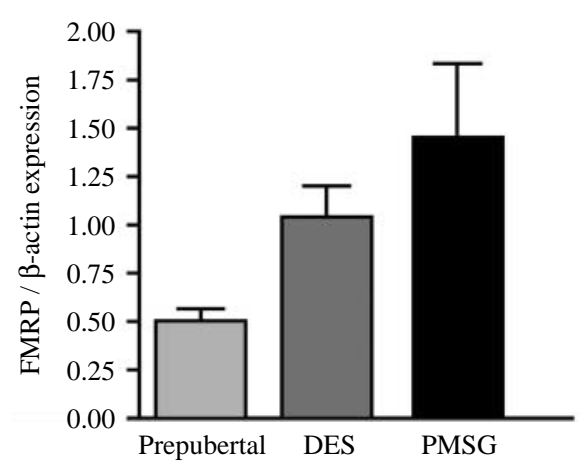

Figure 2 Expression analysis of FMRP. (A; Upper panel) Expression in preantral follicles from prepubertal rats (prepubertal), early antral follicles from DES-treated rats (DES) and preovulatory follicles from PMSG-treated rats (PMSG). (Lower panel) Densitometric quantification of FMRP expressed in follicles. Bars represent the mean \pm s.E.M. normalized to $\beta$-actin of three different extracts. (B) Expression of FMRP in rat testis, brain and preovulatory follicle. (C) Expression in early antral follicles and in rat muscle. A $12 \mu \mathrm{g}$ sample of protein was loaded in all cases except for testis where $5 \mu \mathrm{g}$ was used. Representative immunoblots are shown. 

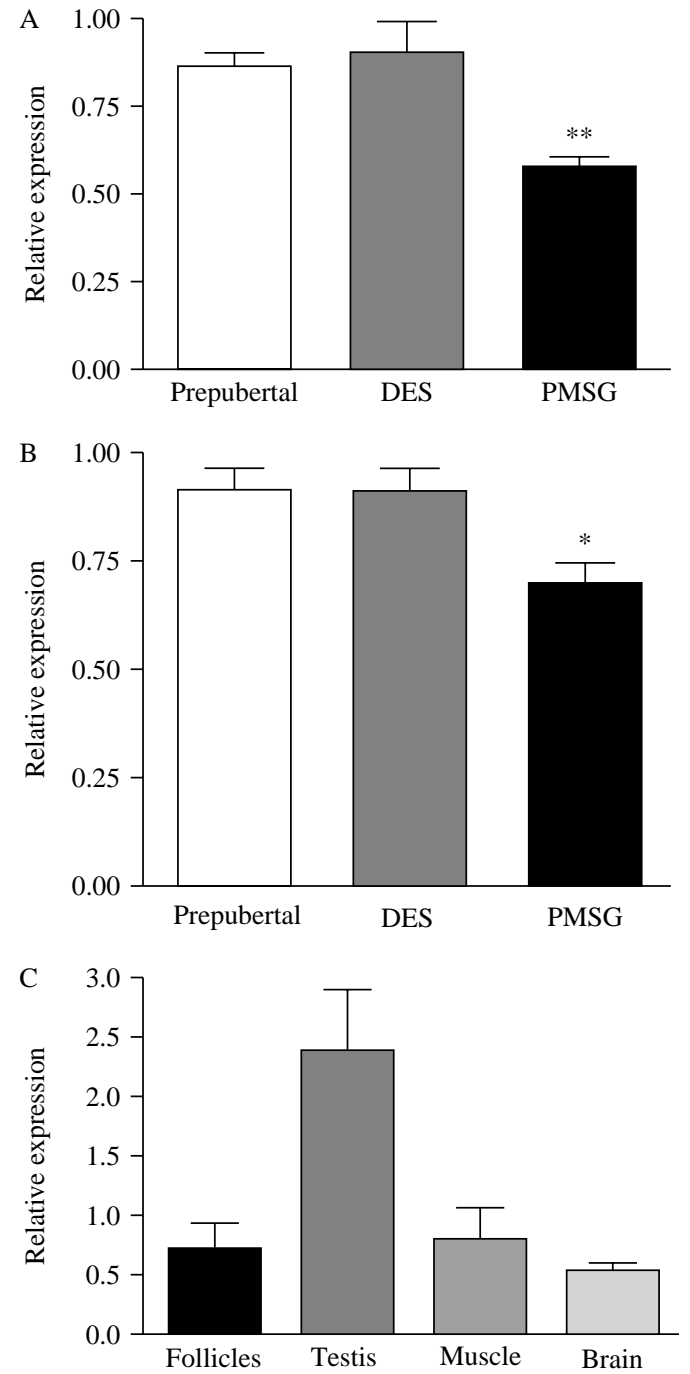

Figure 3 Quantitative estimate of Fmr1 mRNA levels by qRT-PCR. Relative expression of FMRP in follicles (A) and ovary (B). Levels are plotted relative to FMRP expression in prepubertal rats (A and $B$ ). ${ }^{* *} P<0.01 ;{ }^{*} P<0.05$. Each bar represents mean \pm s.E.M. (C) Relative expression of FMRP in rat follicles, testis, muscle and brain. Levels are plotted relative to FMRP expression in follicles.

the maturation of a large cohort of follicles that synchronously progress through small- to mediumsized antral and preovulatory stages respectively (Rani et al. 1983, Karakji \& Tsang 1995). The DES and PMSG treatments are widely used as models to study follicular dynamics under physiological conditions (Billig et al. 1993, Chun et al. 1996, Li et al. 1998).

By immnuhistochemical studies, we detected FMRP expression at all stages of follicular development, including the germ cell. GC and TC from untreated, DES- and PMSG-treated rats showed positive FMRP immunostaining. It is noteworthy that the changes observed in the different follicular stages induced by the hormonal treatments used are a reflection of data obtained in ovaries from adult cycling rats, suggesting that these observations have a physiological correlate and are not merely the result of the hormonal treatments. In adult rats FMRP immunostaining was also observed in luteal cell indicating a possible role of the protein in corpus luteum function as well. Similarly, FMRP expression was described in mouse female fetal primordial cells and also in follicular cells in the adult (Bakker et al. 2000). Recent works by Hoffman et al. (2012) and Lu et al. (2012) described expression of FMRP in murine granulosa and luteal cells as well as in the oocyte. In addition, FMRP expression in ovaries from women of different ages has also been described, mainly in the oocyte and GCs (Schuettler et al. 2011, Willemsen et al. 2011). In accordance with the nuclear localization and export signals present in the protein (Eberhart et al. 1996), and consistently with the expression of the protein mostly in the cytoplasm (Devys et al. 1993), we detected only a small fraction of cells showing positive FMRP immunostaining in the nucleus.

As a result of the alternative splicing of the Fmr 1 mRNA numerous isoforms of the protein can be synthesized, an argument in favor of particular cellular roles for the individual isoforms (Ashley et al. 1993, Sittler et al. 1996, Denman \& Sung 2002). In addition, phosphorylation and methylation have been described as post-translational modification of FMRP (Siomi et al. 2002, Stetler et al. 2006). Our results showed expression of at least four different isoforms in the rat ovary during all stages of follicular growth. The differences observed in isoform expression patterns in the ovary compared to brain and testis might suggest a specific function for some of the isoforms in this tissue. Strikingly, different levels of all FMRP isoforms are detected by WB during follicular development; a lower protein level was observed in PAF, while expression increased in EAF and $\mathrm{PF}$, and these differences were even more evident during preantral to early antral transition. The preantral to early antral transition is the one most susceptible to atresia (Hirshfield 1991); important changes in protein translation may thus occur during this period to overcome atresia and continue with folliculogenesis. Considering that FMRP is a major cellular translational repressor protein that binds to multiple transcripts thereafter controlling their translation rate (Laggerbauer et al. 2001, Schaeffer et al. 2001, Schuettler et al. 2011), low amounts of the protein during the preantral stage could allow a more permissive translation of target mRNAs, while a progressive repressing state would be expected in developing follicles. As FMRP has been shown to interact with miRNA and the components of the miRNA pathway (Caudy et al. 2002, Ishizuka et al. 2002, Jin et al. 2004), and considering that miRNAs have an important role in post-transcriptional gene regulation in the ovary and in the female reproductive tract in general (Fiedler et al. 2008, Carletti \& Christenson 2009, Christenson 2010), it seems natural to assign to the 
protein a crucial role in the adequate functioning of the gonad. Defects in regulatory control can lead to ovarian failure due to disruption of folliculogenesis, block of ovulation and corpus luteum insufficiency, among others (Carletti \& Christenson 2009). Moreover, ovarian follicle development largely depends on the proliferation of GCs. GC proliferation commences from primary follicle formation, and the follicle growth is characterized by increasing layers of GCs (Zhang et al. 2011). Considering that the GC is the follicular cell type that undergoes the greatest changes in size and number during the development of the follicle, our results could also be a measure of the contribution of the expression of FMRP in this cell type to the regulation of ovarian physiology.

Contrary to results obtained at the protein level, PAF and EAF presented similar levels of Fmr1 transcripts, while decreased expression was observed in PF, suggesting that Fmr1 expression in the ovary is regulated at different and perhaps independent levels. Supporting this idea, even though no FMRP could be detected in muscle, mRNA was expressed in this tissue. Similarly, increased FMRP levels found in the barrel cortex after unilateral whisker stimulation were not accompanied by changes in Fmr1 mRNA (Todd et al. 2003). An increment in either mRNA stability or protein translation rate in the late stages of folliculogenesis might account for the discrepancies found between RNA and protein levels. In line with this contention, the fact that FMRP has been shown to bind to a significant percentage of brain mRNAs, including Fmr1 mRNA itself (Brown et al. 2001, Darnell et al. 2001, Schaeffer et al. 2001, Didiot et al. 2008), and that FMRP has been implicated as a direct modulator of mRNA turnover, has led to suggestion of a possible role for FMRP in mRNA stability (De Rubeis \& Bagni 2010, 2011). However, a direct effect of FMRP on its own mRNA stability remains to be established. Ultimately, our in vivo data could indicate a putative regulation of Fmr1 mRNA levels of enhanced FMRP expression in advanced follicular development.

Several mouse models carrying human FMR1 repeats in the premutation range have been developed. Histological analysis in a knock-in model with 130 CGG repeats revealed ovarian abnormalities (Hoffman et al. 2012). In addition, the characterization of a transgenic mouse carrying a premutation of 90 CGG repeats showed that premutated RNA impaired female fertility, reduced the number of growing follicles and altered selective serum hormone levels, thus resembling FXPOI in humans (Lu et al. 2012). Given the advanced technologies in transgenic and knock-in models in rat, and taking into account the data presented in our work, it would be an interesting challenge to develop a rat model of FXPOI to further contribute to the better understanding of the influence of FMR1 CGG repeats in ovarian pathophysiology.

\section{Conclusions}

This study shows for the first time, to our knowledge the regulated expression of Fmr1, both at the mRNA and protein levels, during rat follicular development. Further studies may be necessary to confirm whether this protein is involved in the functional changes that occur during folliculogenesis.

\section{Materials and Methods}

\section{Animal preparation}

All procedures in this study were approved by the Ethics Committee of the Institute of Biology and Experimental Medicine (IBYME-CONICET) and are in accordance with National Institute of Health standards, as described in the guide for Care and Use of Laboratory Animals.

Prepubertal female Sprague-Dawley rats (18- to 23-days old) and 60-days -old rats were allowed access to food and water ad libitum and kept at room temperature $\left(21-23^{\circ} \mathrm{C}\right)$ on a $12 \mathrm{~h}$ light:12 h darkness cycle.

To obtain ovaries enriched with follicles at different developmental stages, rats were injected s.c. either with DES ( $1 \mathrm{mg} / \mathrm{rat}$, Sigma Chemical Co.) dissolved in corn oil, daily, for 3 days, to stimulate the development of EAF or with a single injection of equine chrorionic gonadotropin (PMSG, $25 \mathrm{IU} / \mathrm{rat}$, Novormon, Syntex S.A. Buenos Aires, Argentina) $48 \mathrm{~h}$ before the experiment, to stimulate the development of PF ( $\mathrm{Li}$ et al. 1998). Ovaries enriched with PAF were obtained from untreated prepubertal rats. Rats were killed by $\mathrm{CO}_{2}$ asphyxiation and ovaries were removed and cleaned of adhering tissue.

\section{Follicle isolation}

For isolation of PAF ovaries obtained from six to twelve 18-day-old rats were minced using 26G1/2 syringe needles according to the method of Flaws et al. (1994). Briefly, minced tissue was dissociated by incubation in $2.5 \mathrm{ml}$ DMEM-F12 (Gibco Laboratories) with HEPES (Sigma Chemical Co.) containing collagenase (4800 units; $217 \mathrm{U} / \mathrm{mg}$; Gibco), DNase (1910 units, $10 \mathrm{mg} / \mathrm{ml}$, D4527, Sigma), and $1 \%$ BSA (A7888, Sigma), in a water shaking bath at $37^{\circ} \mathrm{C}$ for $20 \mathrm{~min}$. The dissociated tissue was then washed three times in DMEM-F12 HEPES and passed through a nylon filter with $210 \mu \mathrm{m}$ pores (Small Parts CMN-210, Miramar, FL, USA). All excluded structures (follicles $>210 \mu \mathrm{m}$ in diameter and corpora lutea) were discarded and follicles smaller than $210 \mu \mathrm{m}$ were considered PAF.

Ovaries from DES- and PMSG-treated rats were used to obtain EAF $(300-400 \mu \mathrm{m})$ and PF $(>450 \mu \mathrm{m})$ follicles respectively. In both cases, individual ovarian follicles were dissected from the ovary under a stereoscopic microscope using fine needles, as described previously (Parborell et al. 2002, Abramovich et al. 2009).

\section{Immunohistochemistry}

Sections of formalin-fixed paraffin-embedded tissue were deparaffinized in xylene and rehydrated in graded ethanol 
washes. Endogenous peroxidase activity was blocked with $3 \%$ hydrogen peroxide in PBS $(\mathrm{pH}$ 7.2) for 20 min followed by successive PBS washes. For antigenic exposure, slides were heated in a microwave oven in citric acid buffer $0.01 \mathrm{M}$ $(\mathrm{pH}=6)$ for $10 \mathrm{~min}$ at $600 \mathrm{~W}$. Nonspecific binding was blocked with $2 \%$ BSA for $20 \mathrm{~min}$. Sections were incubated overnight at $4{ }^{\circ} \mathrm{C}$ in a humidified chamber with or without (negative control) anti-FMRP antibody in PBS (1/400, clone 1C3, Millipore, Billerica, MA, USA). Slides were washed in PBS and FMRP detected with a biotin-conjugated goat anti-mouse IgG (1/400, 30 min, RT, Vector Laboratories, Burlingame, CA, USA) followed by avidin-biotinylated HRP complex (Vectastain ABC system; Vector Laboratories) for $30 \mathrm{~min}$. Immunoreactivity was visualized with diaminobenzidine staining. The reaction was stopped with distilled water, stained with hematoxylin, dehydrated in graded alcohols and mounted. For a better visualization of the putative expression in the nucleus, no hematoxylin counterstain was used. The appearance of a brown reaction product was observed by light microscope.

\section{Western blot}

For WB analyses, either ovarian tissue from three or four rats or isolated follicles from 12 to 24 ovaries per treatment were pooled and resuspended in $600 \mu \mathrm{l}$ lysis buffer $(20 \mathrm{mM}$ Tris- $\mathrm{HCl}, \mathrm{pH}$ 8, $137 \mathrm{mM} \mathrm{NaCl}, 1 \% \mathrm{NP}-40$ and 10\% glycerol) supplemented with protease inhibitors (104 mM 4-(2-Aminoethyl) benzenesulfonyl fluoride hydrochloride (AEBSF) $80 \mu \mathrm{M}$ aprotinin, $4 \mathrm{mM}$ bestatin, $1.4 \mathrm{mM}$ E-64, $2 \mathrm{mM}$ leupeptin, and $1.5 \mathrm{mM}$ pepstatin A, Sigma) and homogenized with an Ultra-Turrax (IKA Werk, Breisgau, Germany) homogenizer. The results obtained from each pool of ovarian tissue or follicles were considered a single datum.

Assays were performed according to the methodology described by Feng et al. (1997), with slight modifications. Briefly, samples were centrifuged at $4{ }^{\circ} \mathrm{C}$ for $15 \mathrm{~min}$ at $16000 \mathrm{~g}$, and the resulting supernatant centrifuged at $4{ }^{\circ} \mathrm{C}$ for $1 \mathrm{~h}$ at $150000 \mathrm{~g}$ to obtain a pellet enriched in ribosomes. The supernatant was discarded and the pellet was resuspended in urea buffer (1\% Triton-X, 100 mM Tris- $\mathrm{HCl}, \mathrm{pH} 6.8$, and $6 \mathrm{M}$ urea). Protein concentration was measured by the Bradford assay.

As control tissues, testis, brain and muscle were obtained, homogenized, and centrifuged as described earlier. Lysis buffer for muscle homogenization contained $50 \mathrm{mM}$ Tris- $\mathrm{HCl}(\mathrm{pH}$ 7.5), $1 \mathrm{mM}$ EDTA, $1 \mathrm{mM}$ EGTA, $150 \mathrm{mM} \mathrm{NaCl}, 10 \%$ glycerol, $1 \%$ NP-40, $0.1 \%$ SDS, and $1 \mathrm{mM} \mathrm{MgCl}$. Brain buffer contained $40 \mathrm{mM}$ Tris- $\mathrm{HCl}, 120 \mathrm{mM} \mathrm{NaCl}, 2 \mathrm{mM} \mathrm{Na} \mathrm{VO}_{4}$, $1 \%$ Triton-X 100, and $1 \mathrm{mM}$ PMSF. For testis homogenization, the same buffer as for follicles and ovaries was used. A total of $12 \mu \mathrm{g}$ protein was loaded on 7.5\% SDS-PAGE was performed at $25 \mathrm{~mA}$ for $1.5 \mathrm{~h}$. Proteins were transferred into a nitrocellulose membrane for $1 \mathrm{~h}$. FMRP and $\beta$-actin blots were blocked at $4{ }^{\circ} \mathrm{C}$ overnight in PBS containing low-fat powdered milk $(5 \%)$ and Tween $20(0.2 \%)$ followed by incubation with mouse monoclonal anti-FMRP 1C3 (1/4000) or mouse anti- $\beta$-actin (1/10 000 ab-6276 Abcam; Cambridge Science Park, UK) for $2 \mathrm{~h}$ at room temperature in $0.2 \%$ Tween 20 in PBS. S6 blots were blocked in the same blocking solution as described earlier for $1 \mathrm{~h}$ at room temperature and incubated with anti-mouse monoclonal S6 antibody (1/1000, 54D2, Cell Signaling, Danvers, MA, USA) in blocking solution overnight at $4{ }^{\circ} \mathrm{C}$. Anti-mouse antibody conjugated to HRP was used as a secondary antibody, and the signal was detected by chemiluminescence and autoradiography. For quantification screening was performed with X-ray film using different times of exposure to optimize the signal. Protein levels were compared and analyzed by densitometry using the Image J software (NIH). The density of each band was normalized to the density of the $\beta$-actin band used as an internal control. Three independent protein extracts were obtained for each experimental group.

\section{Real-time RT-PCR}

To quantify Fmr1 mRNA levels in DES- or PMSG-treated rats, whole ovaries or isolated follicles from four rats were used. Each rat extract was assayed individually. For the prepubertal group, four rats were used when the whole ovary was assayed, while three groups of six rats each were used for isolated follicles.

Total RNA was extracted using Trizol reagent (MRC, Cincinatti $\mathrm{OH}$, USA) according to manufacturer's instructions. Purified RNA was stored at $-70{ }^{\circ} \mathrm{C}$ until cDNA synthesis. Complementary DNA templates for PCR amplification were synthesized from $1 \mu \mathrm{g}$ total RNA using random primers and M-MLV Reverse Transcriptase (Promega) in a total volume of $25 \mu \mathrm{l}$. Before real-time PCR studies, CDNA synthesis was verified by regular PCR using primers for Fmr 1 and running at $94^{\circ} \mathrm{C}$ for $1.5 \mathrm{~min}$, following with 35 cycles at $94^{\circ} \mathrm{C}$ for $40 \mathrm{~s}, 56{ }^{\circ} \mathrm{C}$ for $30 \mathrm{~s}, 72{ }^{\circ} \mathrm{C}$ for $1.5 \mathrm{~min}$, and a final extension at $72{ }^{\circ} \mathrm{C}$ for $10 \mathrm{~min}$. Results were monitored by agarose gel electrophoresis.

Real-time PCR was performed using SYBR GREEN PCR Master Mix (Applied Biosystems) and the forward $5^{\prime}$-agatcaagctggaggtgcca-3' and reverse 5'-cagagaaggcaccaactgcc- $3^{\prime}$ primers (Brouwer et al. 2007). Cycling conditions were as follows: 1 cycle of $50{ }^{\circ} \mathrm{C}$ for $2 \mathrm{~min}, 95^{\circ} \mathrm{C}$ for $10 \mathrm{~min}$, 40 cycles of $95^{\circ} \mathrm{C}$ for $15 \mathrm{~s}$, and $60^{\circ} \mathrm{C}$ for $1 \mathrm{~min}$. Results were normalized to the HPRT1 gene (forward primer $5^{\prime}$-gctgaagattggaaaaggtg- $3^{\prime}$; reverse primer $5^{\prime}$-aatccagcaggtcagcaaag- $3^{\prime}$ ) (Hvid et al. 2011) using the Pffafl mathematical model for relative quantification. Each cDNA sample was run in triplicate. RNA was obtained in three independent experiments for the three groups of rats, and each extract assayed at least two times.

\section{Statistical analysis}

Data are expressed as the mean \pm S.E.M. of three experiments. Representative gels of WB are shown in the figures. Statistical analysis was performed by ANOVA followed by the Bonferroni test or by Kruskal-Wallis followed by the Dunn test. Values of $P<0.05$ were considered significant.

\section{Declaration of interest}

The authors declare that there is no conflict of interest that could be perceived as prejudicing the impartiality of the research reported. 


\section{Funding}

This work was partially supported by grants from the National Agency of Scientific and Technologic Promotion (PICT 2006 00208, L Dain), the University of Buenos Aires (UBACyT X059, L Dain), Fondos concursables ANLIS 2010-2011 (L Dain), and the Roemmers Foundation ( $\mathrm{V}$ Chiauzzi).

\section{Acknowledgements}

The authors thank Dr Rob Willemsen for his invaluable help and advice with our initial immunohistochemistry and western blot experiments in rat ovaries and for the gift of the anti-FMRP antibody. They also thank Dr Dalhia Abramovich for her kind help in setting up immunohistochemistry conditions and Dr Lucrecia Piñero Calvo for helpful revision of the manuscript.

\section{References}

Abramovich D, Rodriguez Celin A, Hernandez F, Tesone M \& Parborell F 2009 Spatiotemporal analysis of the protein expression of angiogenic factors and their related receptors during folliculogenesis in rats with and without hormonal treatment. Reproduction 137 309-320. (doi:10.1530/ REP-08-0130)

Allingham-Hawkins DJ, Babul-Hirji R, Chitayat D, Holden JJ, Yang KT, Lee C, Hudson R, Gorwill H, Nolin SL, Glicksman A et al. 1999 Fragile X premutation is a significant risk factor for premature ovarian failure: the International Collaborative POF in fragile X study - preliminary data. American Journal of Medical Genetics 83 322-325. (doi:10.1002/ (SICl)1096-8628(19990402)83:4 <322::AID-AJMG17 > 3.0.CO;2-B)

Ashley CT, Sutcliffe JS, Kunst CB, Leiner HA, Eichler EE, Nelson DL \& Warren ST 1993 Human and murine FMR-1: alternative splicing and translational initiation downstream of the CGG-repeat. Nature Genetics 4 244-251. (doi:10.1038/ng0793-244)

Bachner D, Manca A, Steinbach P, Wohrle D, Just W, Vogel W, Hameister H \& Poustka A 1993 Enhanced expression of the murine FMR1 gene during germ cell proliferation suggests a special function in both the male and the female gonad. Human Molecular Genetics 2 2043-2050. (doi:10.1093/hmg/2.12.2043)

Bakker CE, de Diego Otero Y, Bontekoe C, Raghoe P, Luteijn T, Hoogeveen AT, Oostra BA \& Willemsen R 2000 Immunocytochemical and biochemical characterization of FMRP, FXR1P, and FXR2P in the mouse. Experimental Cell Research 258 162-170. (doi:10.1006/excr. 2000.4932)

Bell MV, Hirst MC, Nakahori Y, MacKinnon RN, Roche A, Flint TJ, Jacobs PA, Tommerup N, Tranebjaerg L, Froster-Iskenius U et al. 1991 Physical mapping across the fragile $\mathrm{X}$ : hypermethylation and clinical expression of the fragile X syndrome. Cell 64 861-866. (doi:10.1016/ 0092-8674(91)90514-Y)

Billig H, Furuta I \& Hsueh AJ 1993 Estrogens inhibit and androgens enhance ovarian granulosa cell apoptosis. Endocrinology 133 2204-2212. (doi:10.1210/en.133.5.2204)

Blackwell E \& Ceman S 2012 Arginine methylation of RNA-binding proteins regulates cell function and differentiation. Molecular Reproduction and Development 79 163-175. (doi:10.1002/mrd.22024)

Blackwell E, Zhang X \& Ceman S 2010 Arginines of the RGG box regulate FMRP association with polyribosomes and mRNA. Human Molecular Genetics 19 1314-1323. (doi:10.1093/hmg/ddq007)

Brouwer JR, Mientjes EJ, Bakker CE, Nieuwenhuizen IM, Severijnen LA, Van der Linde HC, Nelson DL, Oostra BA \& Willemsen R 2007 Elevated Fmr1 mRNA levels and reduced protein expression in a mouse model with an unmethylated fragile $X$ full mutation. Experimental Cell Research 313 244-253. (doi:10.1016/j.yexcr.2006.10.002)

Brown V, Jin P, Ceman S, Darnell JC, O'Donnell WT, Tenenbaum SA, Jin X, Feng Y, Wilkinson KD, Keene JD et al. 2001 Microarray identification of FMRP-associated brain mRNAs and altered mRNA translational profiles in fragile X syndrome. Cell 107 477-487. (doi:10.1016/S0092-8674 (01)00568-2)
Carletti MZ \& Christenson LK 2009 MicroRNA in the ovary and female reproductive tract. Journal of Animal Science 87 E29-E38. (doi:10.2527/ jas.2008-1331)

Caudy AA, Myers M, Hannon GJ \& Hammond SM 2002 Fragile X-related protein and VIG associate with the RNA interference machinery. Genes and Development 16 2491-2496. (doi:10.1101/gad.1025202)

Ceman S, Brown V \& Warren ST 1999 Isolation of an FMRP-associated messenger ribonucleoprotein particle and identification of nucleolin and the fragile X-related proteins as components of the complex. Molecular and Cellular Biology 19 7925-7932.

Ceman S, Nelson R \& Warren ST 2000 Identification of mouse YB1/p50 as a component of the FMRP-associated mRNP particle. Biochemical and Biophysical Research Communications 279 904-908. (doi:10.1006/ bbrc.2000.4035)

Ceman S, O'Donnell WT, Reed M, Patton S, Pohl J \& Warren ST 2003 Phosphorylation influences the translation state of FMRP-associated polyribosomes. Human Molecular Genetics 12 3295-3305. (doi:10.1093/ hmg/ddg350)

Cheever A \& Ceman S 2009 Phosphorylation of FMRP inhibits association with Dicer. RNA 15 362-366. (doi:10.1261/rna.1500809)

Christenson LK 2010 MicroRNA control of ovarian function. Animal Reproduction 7 129-133.

Chun SY, Eisenhauer KM, Minami S, Billig H, Perlas E \& Hsueh AJ 1996 Hormonal regulation of apoptosis in early antral follicles: folliclestimulating hormone as a major survival factor. Endocrinology 137 1447-1456. (doi:10.1210/en.137.4.1447)

Costa A, Wang Y, Dockendorff TC, Erdjument-Bromage H, Tempst P, Schedl P \& Jongens TA 2005 The Drosophila fragile X protein functions as a negative regulator in the orb autoregulatory pathway. Developmental Cell 8 331-342. (doi:10.1016/j.devcel.2005.01.011)

Darnell JC, Jensen KB, Jin P, Brown V, Warren ST \& Darnell RB 2001 Fragile X mental retardation protein targets $\mathrm{G}$ quartet $\mathrm{mRNAs}$ important for neuronal function. Cell 107 489-499. (doi:10.1016/S0092-8674(01)00566-9)

Denman RB 2002 Methylation of the arginine-glycine-rich region in the fragile $X$ mental retardation protein FMRP differentially affects RNA binding. Cellular \& Molecular Biology Letters 7 877-883.

Denman RB \& Sung YJ 2002 Species-specific and isoform-specific RNA binding of human and mouse fragile $\mathrm{X}$ mental retardation proteins. Biochemical and Biophysical Research Communications 292 1063-1069. (doi:10.1006/bbrc.2002.6768)

De Rubeis S \& Bagni C 2010 Fragile X mental retardation protein control of neuronal mRNA metabolism: insights into mRNA stability. Molecular and Cellular Neurosciences 43 43-50. (doi:10.1016/j.mcn.2009.09.013)

De Rubeis S \& Bagni C 2011 Regulation of molecular pathways in the fragile X syndrome: insights into autism spectrum disorders. Journal of Neurodevelopmental Disorders 3 257-269. (doi:10.1007/s11689-011-9087-2)

Devys D, Lutz Y, Rouyer N, Bellocq JP \& Mandel JL 1993 The FMR-1 protein is cytoplasmic, most abundant in neurons and appears normal in carriers of a fragile X premutation. Nature Genetics 4 335-340. (doi:10.1038/ng0893-335)

Didiot MC, Tian Z, Schaeffer C, Subramanian M, Mandel JL \& Moine H 2008 The G-quartet containing FMRP binding site in FMR1 mRNA is a potent exonic splicing enhancer. Nucleic Acids Research 36 4902-4912. (doi:10.1093/nar/gkn472)

Dolzhanskaya N, Merz G, Aletta JM \& Denman RB 2006 Methylation regulates the intracellular protein-protein and protein-RNA interactions of FMRP. Journal of Cell Science 119 1933-1946. (doi:10.1242/jcs.02882)

Eberhart DE, Malter HE, Feng Y \& Warren ST 1996 The fragile X mental retardation protein is a ribonucleoprotein containing both nuclear localization and nuclear export signals. Human Molecular Genetics 5 1083-1091. (doi:10.1093/hmg/5.8.1083)

Eichler EE, Richards S, Gibbs RA \& Nelson DL 1993 Fine structure of the human FMR1 gene. Human Molecular Genetics 2 1147-1153. (doi:10.1093/hmg/2.8.1147)

Epstein AM, Bauer CR, Ho A, Bosco G \& Zarnescu DC 2009 Drosophila fragile $X$ protein controls cellular proliferation by regulating cbl levels in the ovary. Developmental Biology 330 83-92. (doi:10.1016/j.ydbio. 2009.03.011)

Feng Y, Gutekunst CA, Eberhart DE, Yi H, Warren ST \& Hersch SM 1997 Fragile $\mathrm{X}$ mental retardation protein: nucleocytoplasmic shuttling and association with somatodendritic ribosomes. Journal of Neuroscience 17 1539-1547. 
Fiedler SD, Carletti MZ, Hong X \& Christenson LK 2008 Hormonal regulation of MicroRNA expression in periovulatory mouse mural granulosa cells. Biology of Reproduction 79 1030-1037. (doi:10.1095/ biolreprod.108.069690)

Flaws JA, Doerr JK, Sipes IG \& Hoyer PB 1994 Destruction of preantral follicles in adult rats by 4-vinyl-1-cyclohexene diepoxide. Reproductive Toxicology 8 509-514. (doi:10.1016/0890-6238(94)90033-7)

Fu YH, Kuhl DP, Pizzuti A, Pieretti M, Sutcliffe JS, Richards S, Verkerk AJ, Holden JJ, Fenwick RG Jr, Warren ST et al. 1991 Variation of the CGG repeat at the fragile $X$ site results in genetic instability: resolution of the Sherman paradox. Cell 67 1047-1058. (doi:10.1016/0092-8674(91)90283-5)

Garcia-Arocena D \& Hagerman PJ 2010 Advances in understanding the molecular basis of FXTAS. Human Molecular Genetics 19 R83-R89. (doi:10.1093/hmg/ddq166)

Hirshfield AN 1991 Development of follicles in the mammalian ovary. International Review of Cytology 124 43-101.

Hirshfield AN \& Midgley AR Jr 1978 Morphometric analysis of follicular development in the rat. Biology of Reproduction 19 597-605. (doi:10.1095/biolreprod19.3.597)

Hoffman GE, Le WW, Entezam A, Otsuka N, Tong ZB, Nelson L, Flaws JA, McDonald JH, Jafar S \& Usdin K 2012 Ovarian abnormalities in a mouse model of fragile X primary ovarian insufficiency. Journal of Histochemistry and Cytochemistry 60 439-456. (doi:10.1369/0022155412441002)

Hvid H, Ekstrom CT, Vienberg S, Oleksiewicz MB \& Klopfleisch R 2011 Identification of stable and oestrus cycle-independent housekeeping genes in the rat mammary gland and other tissues. Veterinary Journal 190 103-108. (doi:10.1016/j.tvjl.2010.09.002)

Ishizuka A, Siomi MC \& Siomi H 2002 A Drosophila fragile X protein interacts with components of RNAi and ribosomal proteins. Genes and Development 16 2497-2508. (doi:10.1101/gad.1022002)

Jin P, Zarnescu DC, Ceman S, Nakamoto M, Mowrey J, Jongens TA, Nelson DL, Moses K \& Warren ST 2004 Biochemical and genetic interaction between the fragile $X$ mental retardation protein and the microRNA pathway. Nature Neuroscience 7 113-117. (doi:10.1038/nn1174)

Karakji EG \& Tsang BK 1995 Follicular stage-dependent regulation of rat granulosa cell plasminogen activator system by transforming growth factor- $\alpha$ in vitro. Biology of Reproduction 52 411-418. (doi:10.1095/ biolreprod52.2.411)

Khandjian EW, Bardoni B, Corbin F, Sittler A, Giroux S, Heitz D, Tremblay S, Pinset C, Montarras D, Rousseau F et al. 1998 Novel isoforms of the fragile $X$ related protein FXR1Pare expressed during myogenesis. Human Molecular Genetics 7 2121-2128. (doi:10.1093/hmg/7.13.2121)

Laggerbauer B, Ostareck D, Keidel EM, Ostareck-Lederer A \& Fischer U 2001 Evidence that fragile $X$ mental retardation protein is a negative regulator of translation. Human Molecular Genetics 10 329-338. (doi:10.1093/hmg/10.4.329)

Li J, Kim JM, Liston P, Li M, Miyazaki T, Mackenzie AE, Korneluk RG \& Tsang BK 1998 Expression of inhibitor of apoptosis proteins (IAPs) in rat granulosa cells during ovarian follicular development and atresia. Endocrinology 139 1321-1328. (doi:10.1210/en.139.3.1321)

Lu C, Lin L, Tan H, Wu H, Sherman SL, Gao F, Jin P \& Chen D 2012 Fragile X premutation RNA is sufficient to cause primary ovarian insufficiency in mice. Human Molecular Genetics 21 5039-5047. (doi:10.1093/hmg/dds348)

Mazroui R, Huot ME, Tremblay S, Filion C, Labelle Y \& Khandjian EW 2002 Trapping of messenger RNA by fragile $X$ mental retardation protein into cytoplasmic granules induces translation repression. Human Molecular Genetics 11 3007-3017. (doi:10.1093/hmg/11.24.3007)

Megosh HB, Cox DN, Campbell C \& Lin H 2006 The role of PIWI and the miRNA machinery in Drosophila germline determination. Current Biology 16 1884-1894. (doi:10.1016/j.cub.2006.08.051)

Oberle I, Rousseau F, Heitz D, Kretz C, Devys D, Hanauer A, Boue J, Bertheas M \& Mandel J 1991 Instability of a 550-base pair DNA segment and abnormal methylation in fragile $X$ syndrome. Science 252 1097-1102. (doi:10.1126/science.252.5009.1097)

O'Donnell WT \& Warren ST 2002 A decade of molecular studies of fragile X syndrome. Annual Review of Neuroscience 25 315-338. (doi:10.1146/ annurev.neuro.25.112701.142909)

Parborell F, Pecci A, Gonzalez O, Vitale A \& Tesone M 2002 Effects of a gonadotropin-releasing hormone agonist on rat ovarian follicle apoptosis: regulation by epidermal growth factor and the expression of Bcl-2-related genes. Biology of Reproduction 67 481-486. (doi:10. 1095/biolreprod67.2.481)
Rani CS, Nordenstrom K, Norjavaara E \& Ahren K 1983 Development of catecholamine responsiveness in granulosa cells from preovulatory rat follicles - dependence on preovulatory luteinizing hormone surge. Biology of Reproduction 28 1021-1031. (doi:10.1095/biolreprod28.5.1021)

Rousseau F, Rouillard P, Morel ML, Khandjian EW \& Morgan K 1995 Prevalence of carriers of premutation-size alleles of the FMRI gene - and implications for the population genetics of the fragile $X$ syndrome. American Journal of Human Genetics 57 1006-1018.

Schaeffer C, Bardoni B, Mandel JL, Ehresmann B, Ehresmann C \& Moine H 2001 The fragile $X$ mental retardation protein binds specifically to its mRNA via a purine quartet motif. EMBO Journal 20 4803-4813. (doi:10.1093/emboj/20.17.4803)

Schuettler J, Peng Z, Zimmer J, Sinn P, von Hagens C, Strowitzki T \& Vogt PH 2011 Variable expression of the fragile $X$ mental retardation 1 (FMR1) gene in patients with premature ovarian failure syndrome is not dependent on number of (CGG)n triplets in exon 1. Human Reproduction 26 1241-1251. (doi:10.1093/humrep/der018)

Sherman SL 2000 Premature ovarian failure in the fragile $X$ syndrome. American Journal of Medical Genetics 97 189-194. (doi:10.1002/10968628(200023)97:3 < 189::AID-AJMG1036>3.0.CO;2-J)

Siomi MC, Higashijima K, Ishizuka A \& Siomi H 2002 Casein kinase II phosphorylates the fragile $\mathrm{X}$ mental retardation protein and modulates its biological properties. Molecular and Cellular Biology 22 8438-8447. (doi:10.1128/MCB.22.24.8438-8447.2002)

Sittler A, Devys D, Weber C \& Mandel JL 1996 Alternative splicing of exon 14 determines nuclear or cytoplasmic localisation of fmr1 protein isoforms. Human Molecular Genetics 5 95-102. (doi:10.1093/hmg/5.1.95)

Stetler A, Winograd C, Sayegh J, Cheever A, Patton E, Zhang X, Clarke S \& Ceman S 2006 Identification and characterization of the methyl arginines in the fragile $\mathrm{X}$ mental retardation protein Fmrp. Human Molecular Genetics 15 87-96. (doi:10.1093/hmg/ddi429)

Tamanini F, Meijer N, Verheij C, Willems PJ, Galjaard H, Oostra BA \& Hoogeveen AT 1996 FMRP is associated to the ribosomes via RNA. Human Molecular Genetics 5 809-813. (doi:10.1093/hmg/5.6.809)

Tamanini F, Willemsen R, van Unen L, Bontekoe C, Galjaard H, Oostra BA \& Hoogeveen AT 1997 Differential expression of FMR1, FXR1 and FXR2 proteins in human brain and testis. Human Molecular Genetics 6 1315-1322. (doi:10.1093/hmg/6.8.1315)

Tassone F, Hagerman RJ, Taylor AK, Gane LW, Godfrey TE \& Hagerman PJ 2000 Elevated levels of FMR1 mRNA in carrier males: a new mechanism of involvement in the fragile-X syndrome. American Journal of Human Genetics 66 6-15. (doi:10.1086/302720)

Tassone F, Beilina A, Carosi C, Albertosi S, Bagni C, Li L, Glover K, Bentley D \& Hagerman PJ 2007 Elevated FMR1 mRNA in premutation carriers is due to increased transcription. RNA 13 555-562. (doi:10.1261/rna.280807)

Todd PK, Malter JS \& Mack KJ 2003 Whisker stimulation-dependent translation of FMRP in the barrel cortex requires activation of type I metabotropic glutamate receptors. Brain Research. Molecular Brain Research 110 267-278. (doi:10.1016/S0169-328X(02)00657-5)

Verkerk AJ, de Graaff E, De Boulle K, Eichler EE, Konecki DS, Reyniers E, Manca A, Poustka A, Willems PJ, Nelson DL et al. 1993 Alternative splicing in the fragile X gene FMR1. Human Molecular Genetics 2 399-404. (doi:10.1093/hmg/2.4.399)

Willemsen R, Levenga J \& Oostra BA 2011 CGG repeat in the FMR1 gene: size matters. Clinical Genetics 80 214-225. (doi:10.1111/j.1399-0004. 2011.01723.x)

Yang L, Duan R, Chen D, Wang J \& Jin P 2007 Fragile X mental retardation protein modulates the fate of germline stem cells in Drosophila. Human Molecular Genetics 16 1814-1820. (doi:10.1093/hmg/ddm129)

Zhang CP, Yang JL, Zhang J, Li L, Huang L, Ji SY, Hu ZY, Gao F \& Liu YX 2011 Notch signaling is involved in ovarian follicle development by regulating granulosa cell proliferation. Endocrinology 152 2437-2447. (doi:10.1210/en.2010-1182)

Received 3 August 2012

First decision 15 October 2012

Revised manuscript received 11 December 2012

Accepted 21 January 2013 